\title{
MILIUSA LANCEOLATA (ANNONACEAE), A NEW SPECIES FROM PAPUA NEW GUINEA
}

\author{
T. CHAOWASKU \& P.J.A. KEßLER \\ Nationaal Herbarium Nederland, Universiteit Leiden branch, \\ P.O. Box 9514, 2300 RA Leiden, The Netherlands; \\ e-mail: chaowasku@nhn.leidenuniv.nl; kessler@nhn.leidenuniv.nl
}

\begin{abstract}
SUMMARY
A new species, Miliusa lanceolata Chaowasku \& Keßler (Annonaceae), is described and illustrated. It has been so far recorded from the D'Entrecasteaux Islands (Goodenough and Normanby Islands) and Louisiade Archipelago (Sudest Island), southeast off Papua New Guinea and is characterized by densely hairy young twigs, lanceolate leaves, and supra-axillary flowers with long pedicels. The relationship with similar species in the genus is also discussed and a key to the species of Miliusa in New Guinea is provided.
\end{abstract}

Key words: Annonaceae, Miliusa, Papua New Guinea, new species.

\section{INTRODUCTION}

The genus Miliusa Lesch. ex A.DC. (Annonaceae) possesses about 50 species distributed from India to Australia. It has formerly been grouped in the tribe Miliuseae together with Alphonsea Hook.f. \& Thomson, Mezzettia Becc., Orophea Blume, Phoenicanthus Alston, and Platymitra Boerl. (Keßler, 1993). Recent molecular studies have revealed that this tribe is polyphyletic (Mols et al., 2004; Richardson et al., 2004) and needs to be reclassified. On the basis of macro-morphology, Miliusa is circumscribed by: 1) the similarity in size of sepals and outer petals, the latter are always much smaller than the inner petals; 2) the densely hairy torus; 3 ) the miliusoid stamens (the stamens without connective prolongation covering the thecae); and 4) the 4-part-lamellate rumination of the endosperm. Unlike other genera in the tribe, the morphology of Miliusa is quite heterogeneous and variable with respect to flower position, the inner petals, and the number of ovule(s) per carpel. The inner petals appear to be the key character to distinguish species groups within Miliusa. Some species groups, e.g. the M. mollis Pierre group (c. 10 species), have a glandular-like structure at the base inside the inner petals, while the $M$. horsfieldii (Benn.) Pierre group (c. 10 species, formerly known as genus Saccopetalum Benn.) exhibit a vertically glandular-like band along the midrib inside the inner petals. In contrast, the inner petals of the rest of Miliusa (c. 30 species) show no glandular-like organ, only some discoloration inside near the base is often observed instead. In addition, two subgroups can be recognized within the rest of Miliusa concerning the flower position and the base of the inner petals (axillary flowers with the inner petals that are tightly appressed at the base versus supra-axillary flowers with the inner petals that are totally opening). Consequently, further study is needed to unravel the evolutionary relationship of the whole genus. 
In the course of studying the systematics of Miliusa we found some distinct specimens collected from Papua New Guinea that appear to be an undescribed species. Although a revision of species in the Austro-Malesian including this area has recently been completed (Mols \& Keßler, 2003), there are still several species to be described. The new species herein described, $M$. lanceolata, is mainly characterized by the presence of dense hairs on young twigs and lower surface of the leaf midrib and the supra-axillary flowers with rather long pedicels, the latter reminds of M. macropoda Miq. from Borneo; however, only two ovules are present and that results in much smaller monocarps than those of M. macropoda which usually has five to seven ovules per carpel. The inner petals are slightly saccate at the base and exhibit a little (thickened) discoloration inside near the base; this often occurs in M. macropoda as well. Nevertheless, the stamen and carpel number of M. macropoda which are always over 100 and 50, respectively, are many more than those of the new species which has only 32 stamens and 14 carpels. It is likely that this new species and M. macropoda are allied to M. velutina Hook.f. \& Thomson according to the recent phylogenetic analysis (Mols et al., 2004; Mols et al., submitted), and all probably form a monophyletic group because of the similarity in morphology, i.e. the supra-axillary flowers, the totally opening inner petals and few to several ovules attached laterally in one row. Moreover, the inner petals of this group are usually reflexed at anthesis.

There are three other species of Miliusa reported from New Guinea, M. horsfieldii, M. koolsii (Kosterm.) J. Sinclair and M. novoguineensis Mols \& Keßler. Among those species, M. lanceolata seems to share more affinity with $M$. novoguineensis because they share the supra-axillary flowers (although not always in M. novoguineensis) and the 2 ovules. However, $M$. novoguineensis possesses a reduced number of stamens (less than 10) while there usually are c. 20-200 in other species of Miliusa. The inner petals of $M$. horsfieldii and M. koolsii show a distinct, (slightly) raised, glandular-like band inside along the midrib from the tip to the base where the petals of M. lanceolata and $M$. novoguineensis just show a slightly different colour inside near the base. Furthermore, the ovaries of $M$. horsfieldii and $M$. koolsii contain many more ovules (6-12) which are arranged in two rows.

\section{KEY TO SPECIES OF MILIUSA IN NEW GUINEA}

1a. Pedicels $5.5-9 \mathrm{~cm}$ long . . . . . . . . . . . . . . . . . . . . . . . . . . . . . . . . . .

b. Pedicels usually up to $4 \mathrm{~cm}$ long . . . . . . . . . . . . . . . 2

2a. Inner petals narrowly ovate to oblong, $0.8-1.3$ by $0.1-0.3 \mathrm{~cm}$, base slightly saccate, a distinct, raised glandular-like band absent, stamens 3-9, ovules 2, lateral,

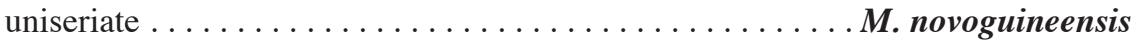

b. Inner petals triangular to ovate, $0.9-4$ by $0.4-1.5 \mathrm{~cm}$, base distinctly saccate, a distinct, (slightly) raised glandular-like band present inside along the midrib from the tip to the base, stamens $24-65$, ovules $6-12$, lateral, biseriate. . . . . . 3

3a. Sepals $\geq 2.5 \mathrm{~mm}$ long. Outer petals $\geq 3.5 \mathrm{~mm}$ long. Inner petals $1.7-4$ by $0.5-1.5$

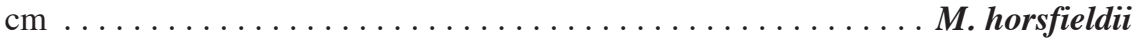

b. Sepals $\leq 1.5 \mathrm{~mm}$ long. Outer petals $\leq 2.5 \mathrm{~mm}$ long. Inner petals $0.9-1.2$ by $0.4-0.7$ $\mathrm{cm}$ 
Miliusa lanceolata Chaowasku \& Keßler, spec. nov. - Fig.1; Map 1

Arbor vel frutex usque ad $8 \mathrm{~m}$ alta. Ramuli juniores villosi. Petioli ca. $1.8 \mathrm{~mm}$ longi, villosi. Folia lanceolata, $6.3-12 \mathrm{~cm}$ longa, $2.2-4.5 \mathrm{~cm}$ lata, basi obtusa vel rotundata, apice acuta vel acuminata, costa supra subcaniculata, nervis lateralibus 6-11 paribus. Cymae supraaxillares, 2-5-floribus, pedunculi 9-20 mm longi, pedicelli 5.5-9 mm longi. Sepala triangulata, $0.9-1.1 \mathrm{~mm}$ longa, $0.7-0.9 \mathrm{~mm}$ lata. Petala exteriora triangulata, $1-1.4 \mathrm{~mm}$ longa, ca. $0.9 \mathrm{~mm}$ lata. Petala interiora triangulata vel ovata, $10-12 \mathrm{~mm}$ longa, $7-9 \mathrm{~mm}$ lata, basi crassiusculi, discolore. Stamina ca. 32, carpella ca. 14, ovulis 2(-3), lateralis. - Typus: Brass 24414 (holo L; iso US), Papua New Guinea, Goodenough Island, Bolu Bolu, 28 September 1953, in flower \& fruit.

Treelets to small (bushy) trees 3-8 m tall. Young twigs villous. Old twigs (almost) glabrous. Petioles c. $1.8 \mathrm{~mm}$ long, villous. Leaves narrowly ovate, $6.3-12$ by $2.2-4.5$ $\mathrm{cm}$, base obtuse to rounded, slightly unequal, apex acute to acuminate, lamina glabrous above, almost glabrous to pilose below including secondary veins, upper surface of midrib slightly sunken, shortly puberulous to (sparsely) villous, raised on lower surface, villous, secondary veins $6-11$ pairs, sometimes with intersecondary ones forming loops, angles with midrib 54-62 ${ }^{\circ}$. Flowers in 2-5-flowered cymes, supra-axillary, usually borne on young twigs, peduncles $9-20 \mathrm{~mm}$ long, almost glabrous to pilose, rachis up to $2.5 \mathrm{~mm}$ long, pedicels $5.5-9 \mathrm{~cm}$ long, almost glabrous to pilose, bract(s) triangular, number depending on the number of flowers per inflorescence, outside (abaxial surface of lamina) and margin puberulous, caducous, bracteole 1 for each flower, triangular, indument same as bract(s). Sepals triangular, slightly connate at base, $0.9-1.1$ by $0.7-0.9$ $\mathrm{mm}$, outside almost glabrous, margin and inside slightly puberulous, usually persistent in fruit. Outer petals triangular, $1-1.4$ by $0.9 \mathrm{~mm}$, outside and margin almost glabrous to puberulous, inside (almost) glabrous. Inner petals triangular to slightly ovate, $10-12$ by 7-9 mm, outside glabrous, inside (almost) glabrous, near margin slightly cobwebbed, veins visible, discoloration zone present near base, a little bit thickened, base slightly saccate. Torus hemispherical, villous between stamens. Stamens c. 32, c. $1.3 \mathrm{~mm}$ long. Carpels c. 14, c. $1.6 \mathrm{~mm}$ long, stigmas globose, ovaries (slightly) puberulous, ovules

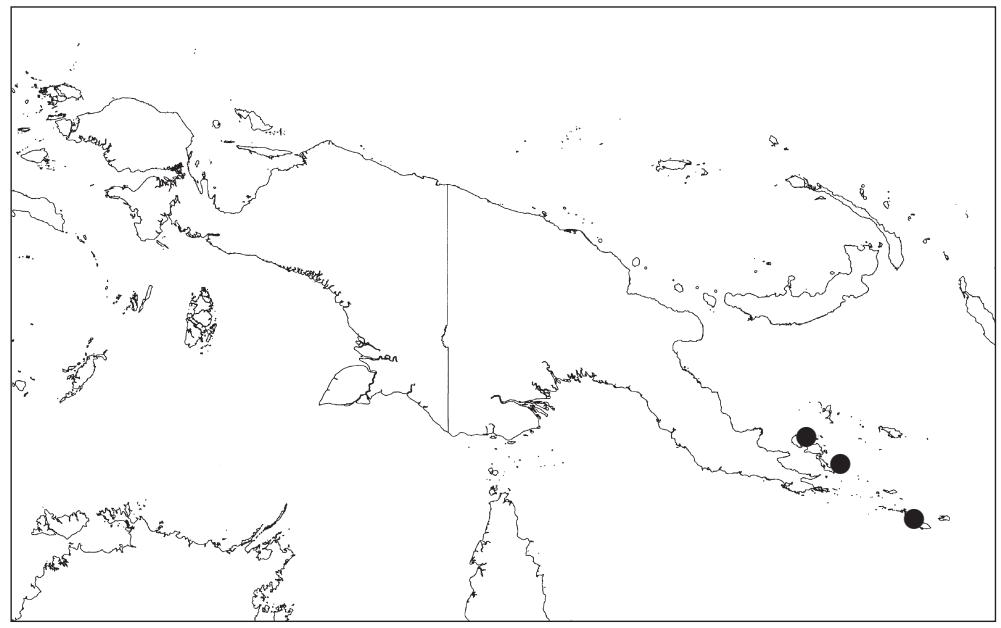

Map 1. Distribution of Miliusa lanceolata Chaowasku \& Keßler. 


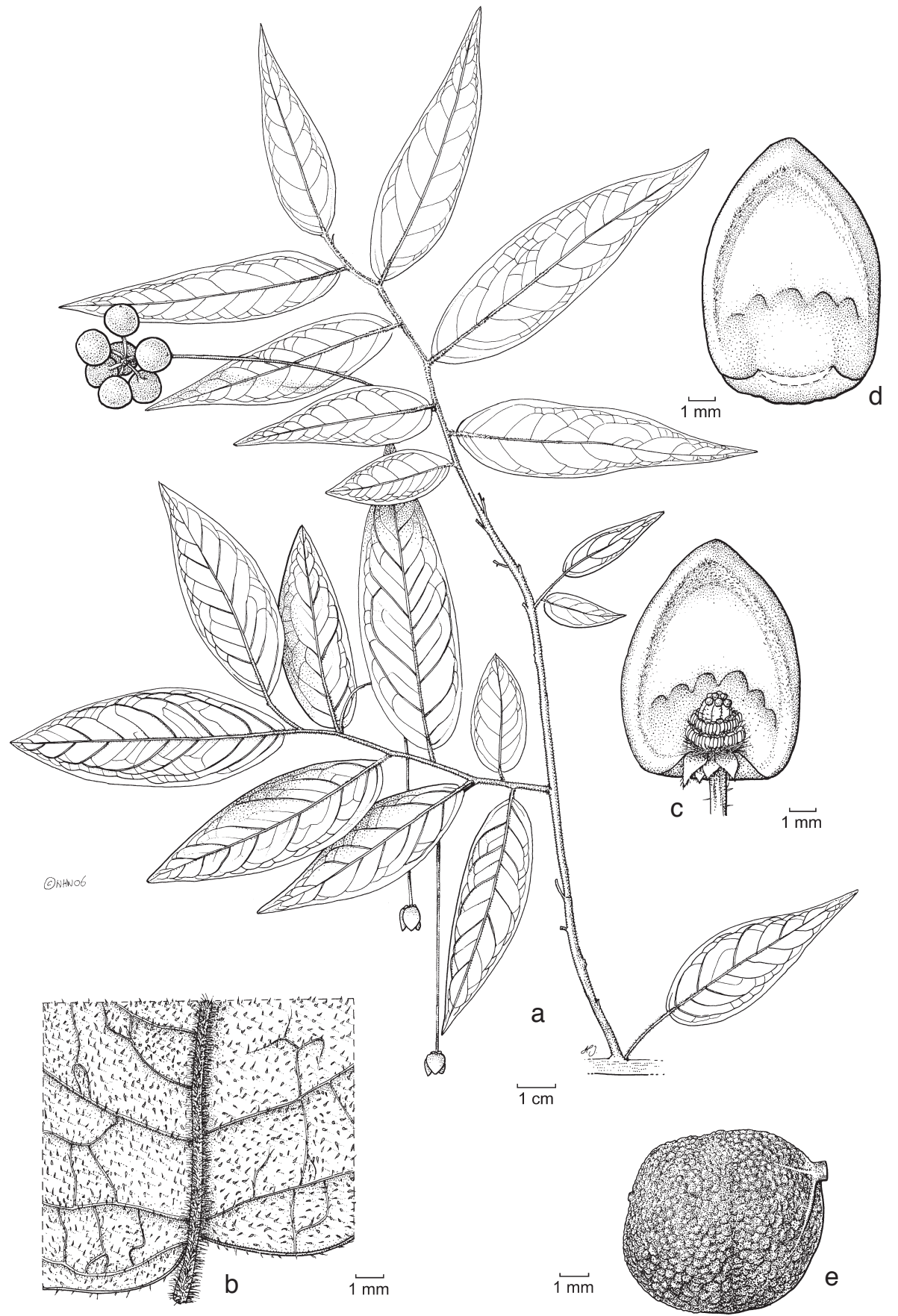

Fig. 1. Miliusa lanceolata Chaowasku \& Keßler. a. Habit; b. lower leaf surface; c. flower with two inner petals removed; d. inside of an inner petal; e. monocarp (all Brass 28198). 
2 (or 3), lateral, uniseriate. Monocarps 6-8, (sub)globose to irregular-shaped, 8-12 by $7-9 \mathrm{~mm}$, constriction of seeds visible if more than 1 seed, surface slightly dotted, not apiculate, stipes 6-10 mm long, smooth to slightly verrucose, glabrous, obliquely attached to the monocarps. Seed(s) 1 or 2 (or 3), (sub)globose, a little bit flattened on one side if more than 1 seed present in a monocarp, c. 7.5 by $4.8-6.5 \mathrm{~mm}$, central groove visible.

Distribution - Papua New Guinea: Goodenough Island, Normanby Island, Sudest Island.

Habitat \& Ecology - Lowland rainforest beside stream or edge of forest on coast. Altitude: 2-20 m. Flowering: September (Brass 24414, 28198). Fruiting: September to October (Brass 24414, 28198, Streimann \& Lelean LAE 52615).

Field notes - Leaves dull dark green above, green below. Flowers green, pendant. Fruits (bright shining) red, globose, about $10 \mathrm{~mm}$ diameter.

Specimens studied:

Brass 24414, Goodenough Island, Bolu Bolu, Milne Bay District, 28-09-1953 (holo L; iso US); Brass 28198, Sudest Island, Rambuso, 21-09-1956 (K, L); Streimann \& Lelean LAE 52615, Normanby Island, Miadeba, Esa'ala Sub-District, Milne Bay District, 23-10-1971, (E, K, L).

\section{ACKNOWLEDGEMENTS}

We would like to thank the curators of E, K, L, and US herbaria for making their materials available for our study. Muhammad Iqbal (NHN-L) is specially acknowledged for his help to create the distribution map. Mrs. Hanneke Jelles (NHN-L) provided us on very short notice the beautiful line drawing which we very much appreciate. We also would like to thank two anonymous reviewers who considerably improved the manuscript. The first author gratefully acknowledges the Royal Thai Government for granting a scholarship and providing an opportunity to study Plant Systematics at Leiden University.

\section{REFERENCES}

Keßler, P.J.A. 1993. Annonaceae. In: K. Kubitzki, J.G. Rohwer \& V. Bittrich (eds.), The families and genera of vascular plants 2: 93-129. Springer Verlag, Berlin, Germany.

Mols, J.B., D.L.V. Co, B. Gravendeel, L.W. Chatrou, M.D. Pirie, R.W.J.M. van der Ham, E.J. van Marle \& P.J.A. Keßler. Submitted. Morphological character evolution in the Miliusoid clade (Annonaceae). Int. J. Pl. Sci.

Mols, J.B., B. Gravendeel, L.W. Chatrou, M.D. Pirie, P.C. Bygrave, M.W. Chase \& P.J.A. Keßler. 2004. Identifying clades in Asian Annonaceae: Monophyletic genera in the polyphyletic Miliuseae. Amer. J. Bot. 91, 4: 590-600.

Mols, J.B. \& P. J.A. Keßler. 2003. The genus Miliusa (Annonaceae) in the Austro-Malesian area. Blumea 48: 421-462.

Richardson, J.E., L.W. Chatrou, J.B. Mols, R.H.J. Erkens \& M.D. Pirie. 2004. Historical biogeography of two cosmopolitan families of flowering plants: Annonaceae and Rhamnaceae. Philos. Trans., Ser. B, 359: 1495-1508. 